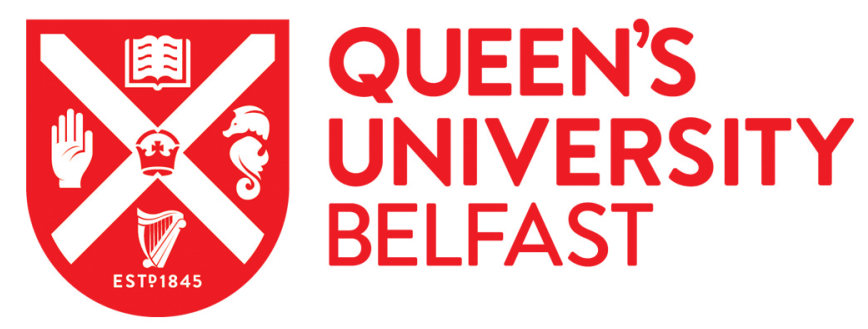

\title{
Race, violence and neoliberalism: crime fiction in the era of Ferguson and Black Lives Matter
}

Pepper, A. (2019). Race, violence and neoliberalism: crime fiction in the era of Ferguson and Black Lives Matter. Textual Practice, 33(6), 963-982. https://doi.org/10.1080/0950236X.2017.1365755

\author{
Published in: \\ Textual Practice
}

Document Version:

Peer reviewed version

Queen's University Belfast - Research Portal:

Link to publication record in Queen's University Belfast Research Portal

\section{Publisher rights}

Copyright 2017 Taylor and Francis.

This work is made available online in accordance with the publisher's policies. Please refer to any applicable terms of use of the publisher.

\section{General rights}

Copyright for the publications made accessible via the Queen's University Belfast Research Portal is retained by the author(s) and / or other copyright owners and it is a condition of accessing these publications that users recognise and abide by the legal requirements associated with these rights.

Take down policy

The Research Portal is Queen's institutional repository that provides access to Queen's research output. Every effort has been made to ensure that content in the Research Portal does not infringe any person's rights, or applicable UK laws. If you discover content in the Research Portal that you believe breaches copyright or violates any law, please contact openaccess@qub.ac.uk. 
Race, violence and neoliberalism: crime fiction in the era of Ferguson and Black Lives Matter

Andrew Pepper, Queen’s University Belfast

\begin{abstract}
:
This paper uses recent instances of police killings of African-American men, and of the retaliatory violence that has flared up in cities across the US (e.g. Ferguson, Baltimore, Baton Rouge), and of the emergence of Black Lives Matters since 2012, as a starting point to think about how well crime fiction can help us to make sense of the larger problem of political violence in the contemporary US. Crime fiction is well-placed to offer insight into the problem of race, drugs, poverty and policing but by paying close attention to The Wire, Walter Mosley's Always Outnumbered, Always Outgunned and Chester Himes's Plan B, I argue that the issue of depicting police violence in a form where the law must also be validated and of accommodating the destructive potentiality of black political violence in a form narratively orientated towards rational explanation and resolution requires very careful consideration. What is different about our contemporary moment is not simply that young black men are being killed by the police or that violent retaliation inevitably follows but rather that these circumstances are also tied to the precariousness experienced by poor black people under neoliberalism. The issue at stake is how exemplary crime fictions make sense of, and critically interrogate, the relationship between race, violence and neoliberalism.
\end{abstract}

\title{
Keywords:
}

Race, violence, neoliberalism, crime fiction, The Wire; Ferguson, Black Lives Matter

\section{Author address:}

Dr Andrew Pepper

School of Arts, English and Languages

Queen's University

Belfast BT7 1NN

a.pepper@qub.ac.uk

Corresponding author: as above 
Race, violence and neoliberalism: crime fiction in the era of Ferguson and Black Lives Matter

What is at stake for contemporary crime fiction following the police killings of unarmed African-Americans in the United States and the reprisal killings of police officers by armed AfricanAmerican men? This article does not seek to address this question head-on. It does not try to consider what can crime fiction tell us specifically about the killing of Michael Brown by a white policeman in Ferguson, Missouri, in August 2014, an event that sparked a violent uprising and brought to national and international prominence the work of Black Lives Matter - an activist group founded in 2012 to draw attention to and campaign against police violence targeting black people in the US. Nor does it ask what light can crime fiction shed on the death of Freddie Gray, after his arrest in Baltimore in April 2015, and the rioting that unfolded there or, indeed, the killing of seven police officers by Micah Johnson, an African-American US army reserve veteran, in Dallas in July 2016. Instead it considers whether or to what extent crime fiction can help to make sense of the larger 'problem' of political violence in US society, i.e. the ongoing state violence perpetrated against black communities and the retaliatory violence exercised by black people in pursuit of political ends.

In one sense, crime fiction is well-placed to offer instructive insight into such complex and fraught issues. After all, a particular kind of US crime fiction (e.g. The Wire, Richard Price's Clockers) is already grounded in the urban realities of crime, drugs, poverty and quasi-militarised policing, and crime fiction has always tried to 'show how the various spaces of a city are connected through acts of violence, and how these connections indicate the spatializations of power within the city. ${ }^{1}$ But, as I'll argue in this article by paying close attention to the HBO-TV series The Wire (2002-2008), Walter Mosley’s Always Outnumbered, Always Outgunned (1997), and Chester Himes's unfinished novel Plan B (1983), the issue of what is at stake when trying to depict police brutality in a form where the law must also be validated, or indeed when trying to accommodate the open-endedness and destructive potentiality of black political violence in a form narratively orientated towards rational explanation and closure, requires careful consideration. 
These examples are very much not post-Ferguson or post-Black Lives Matter. Indeed one could argue that the crime fiction of Ferguson and Black Lives Matter, that is to say, crime fiction that specifically references and engages with these events and the activism they set in motion, is still being written. ${ }^{2}$ Still, the fact that my examples were produced at an earlier moment or in relation to a different set of contexts, and yet are still able to speak to or about the current crisis, suggests a kind of historical continuum. As Ta-Nehisi Coates puts it, 'In America, it is traditional to destroy the black body' and that 'The destroyers are merely men enforcing the whims of our country, correctly interpreting its heritage and legacy'. ${ }^{3}$ Insofar as Coates is able to acknowledge to his son that, 'Your life is so very different from my own' while at the same time situating the killings of 'Eric Garner, Renisha McBride, John Crawford and Tamir Rice’ as part of a continuum going back to slavery and 'the pillaging of life, liberty, labor, and land' ${ }^{4}$ I would like to extend this logic to my treatment of crime fiction. That is to say, I want to argue that my exemplary crime stories depict and negotiate a set of experiences that are part of this racist continuum but that they also speak to what is distinctive about the contemporary moment: not simply that young black men are being killed by the police, or violent retaliations inevitably follow, but rather how the precarity unleashed by capitalism in its neoliberal phrase is disproportionately affecting poor, black lives. As Lester K Spence argues in his ground-breaking book, Knocking the Hustle: Against the Neoliberal Turn (2015), racism alone cannot 'explain why there are some black populations we as black men and women are all too willing to fight for, while there are other black populations we are willing to let die.' Rather, the answer also lies in 'the gradual embrace of the general idea that society (and every institution in it) works best when it works according to the principles of the market. ${ }^{5}$

The first part of this article examines The Wire, notably the third season, as a response to this precarity and poses its highly nuanced reading of the effects of the de-industrialisation of innercity Baltimore and the correlative rise of the drug trade against its more problematic account of the police and black violence. Taking the 2015 Baltimore riots as a starting point, and the public denunciation of the rioting by The Wire's co-creator David Simon, my discussion frames Simon's denunciation, and The Wire's depiction of the Baltimore police force, in relation to a more general unwillingness to characterise black violence as anything except symptom of the drug trade, 
analogised as capitalism in its neoliberal phase. I argue that Simon’s move, following Hannah Arendt, to separate the spheres of politics and violence - that is, to argue that violence has no place in the political process - means that he cannot come to terms with the political significance of what took place in Ferguson and Baltimore. Instead, as a disillusioned Arendtian who passionately believes in 'the ideal of politics as action in the public sphere ${ }^{6}$ but who has witnessed the degradation of this ideal by civic politicians and their capitalist paymasters, Simon leaves himself with nowhere to go, or rather he depicts 'politics' in The Wire as having no forum or outlet for meaningful exchange. As someone who repeatedly and despairingly emphasises the triumph of the free market, meanwhile, he remains handcuffed to a structuralist vision of power that in turn allows no agency for a black population oppressed by capitalism.

Arendt's On Violence (1969) was partly written in response to Franz Fanon's defence of violence in The Wretched of the Earth (1961) and the second section of this article opens by considering Fanon's claims, i.e. that politics and violence are necessarily intertwined and that violent resistance is an important route to political emancipation. It finds affinity between Fanon’s understanding of the ethical potential of embodied violence and the defence of the Ferguson rioters offered by black scholars like Frank B. Wildersson III who claimed, 'It's that mass of Black youth in Ferguson, and not the speeches of Black politicos and certainly not Black ministers that is causing a response. ${ }^{7}$ This is the jumping off point for my consideration of Mosley's Always Outnumbered, Always Outgunned, a collection of linked short stories featuring ex-convict Socrates Fortlow. If Simon is too dismissive of the transformative potential of black violence and presents the disintegration of Baltimore as tragedy for which there is no cure, and the 'Black youth of Ferguson' as characterised by Wildersson, following Fanon, see violence as redemptive and potentially even revolutionary, Mosley's stories offer a more ambiguous account of the usefulness of violence and of the capacity for crime fiction to intervene in and help to order the world it seeks to depict. In response to neoliberalism's emphasis on autonomy, freedom, progress and by extension on the ability of resilient individuals to shape their future, Mosley’s stories emphasise Fortlow’s fear, anxiety, suffering and hesitancy and as such show that emotional and bodily 'affect' does not easily equate to political agency. Rather than giving us a surrogate detective who solves problems and 
arrives at clear-cut answers, who uses violence for redemptive ends, and who in turn produces a narrative that moves inexorably towards resolution and closure, ${ }^{8}$ Mosley’s emphasis on fragmentation and vulnerability (whereby violence produces its own problems and insecurities) enables him to strip down and reassemble the crime novel in such a way that allows him to identify and offer counter-positions to the logic of economic neoliberalism and the precariousness it induces.

Mosley pointedly does not condemn violence, but nor does he celebrate it as a pathway to revolutionary change. In the conclusion I return to Fanon's The Wretched of the Earth which, as Frazer and Hutchings observes, 'begins as the celebration of revolutionary violence' but 'ends up by drawing attention to the corrupting and debilitating effects of violence, whether reactionary or revolutionary, on both perpetrator and victims. ${ }^{, 9}$ This mirrors the move we see in Himes's Plan B, which he started in the late 1960s but didn’t finish and which was first published in France in 1983. In an opening eerily reminiscent of the killing of seven police officers in Dallas in July 2016, a black sniper - enacting Himes’s claims about the efficacy of organised violence ('If there must be violence, I believe it should be organized violence ${ }^{10}$ ) - shoots and kills a number of New York cops before 'the police deploy an even more powerful weapon to retaliate and end his killing spree'. ${ }^{11}$ As the violence spreads and the tit-for-tat retaliations intensify, the result is not revolution but a bloody orgy that destroys everything in its path. Himes may end up in the same place as Fanon but in getting there he shows us how the crime novel, with its historic links to the state, though well-suited to the task of mapping the violence perpetrated by the state on poor black people, struggles to cope when this violence is re-directed, via orchestrated political action, at the state and its proxies.

\section{The Wire - after the Baltimore Uprising}

It was perhaps inevitable that, following the Baltimore uprising in which the death of Freddie Gray, a young black man, in police custody in April 2015 led to spontaneous acts of rioting, looting, destruction to property and anti-police violence, media and political commentators would turn to The Wire. ${ }^{12}$ The HBO-TV series had already made Baltimore infamous as the setting for its portrait of the struggle between drug dealers and the police and by extension of the racial and class 
cleavages ravaging inner city America, and the violence had flared on the same streets where the TV-series had been filmed. More than this, David Simon, the co-creator of The Wire, took to social media on the first night of disturbances to urge the rioters to 'turn around' and 'go home' ${ }^{13}$ and during the aftermath, was widely interviewed by print and online media condemning the violence. For Simon, the riots underscored his Arendtian assertion about the futility and counterproductiveness of violence as a means of achieving political ends: ${ }^{14 ‘}$ The anger which brings mass civil disobedience into the streets, or the anger and selfishness that co-opts that movement into burning a senior center site and a looted liquor store...I value one and I cringe at the diminished authority and moral force of the other. ${ }^{15}$ Violence, for Simon and indeed Arendt, is not just morally wrong; it may be harmful to the real cause of reform insofar as it mobilizes a counter-revolutionary backlash, and leads a cycle of disinvestment and urban blight. ${ }^{16}$ In response to Simon's various assertions, some commentators, like Dave Zirin in The Nation, offered a critical reappraisal of The Wire in light of police violence in the city, arguing that its portrait of 'Baltimore's finest was almost comically kind', ${ }^{17}$ while Coates, in The Atlantic, offered a damning assessment of preaching nonviolence in the face of ongoing police brutality:

When nonviolence is preached as an attempt to evade the repercussions of political brutality, it betrays itself. When nonviolence begins halfway through the war with the aggressor calling time out, it exposes itself as a ruse. When nonviolence is preached by the representatives of the state, when the state doles out heaps of violence to its citizens, it reveals itself to be a con. ${ }^{18}$

For the purposes of this article, I am most interested in thinking about how or to what extent the riots in Baltimore bring to the fore incipient tensions already present in The Wire (rather than using the riots as a stick to beat The Wire with the benefit of hindsight). On the one hand, these include its careful delineation of the effects of neoliberal capitalism on the poorest and most vulnerable citizens (who are, un-coincidentally, mostly black) and its desire to connect the resulting precarity with a set of political decisions taken at a city, state and federal level. On the other hand, they include an unwillingness to depict the kind of police brutality that led to Gray's death or alternatively a desire to limit criticisms of the police to institutional failings and to the damaging 
effects of the 'war on drugs'; a missed opportunity to focus on grassroots mobilisations from within black communities; and an absolute refusal to sanction black violence as anything other than a symptom of the drug trade. In this part of the article, I would like to disentangle these various claims and show how they are the product of what I want to call an Arendtian liberalism aligned to a Marxist structuralism - both of which we can trace back not just to Simon but also to a set of assumptions or a series of tensions that we might see as characteristic of crime fiction in general ${ }^{19}$.

Certainly The Wire has much to say about the anger and despair of being poor and black in the twenty-first century American city. Specifically it addresses the issue of how the restructuring of the US economy and the loss of 'good' manufacturing jobs to cheaper competitors and attendant shifts in the priorities of federal, state and city officials under the auspices of neoliberal reforms (e.g. the diversion of public and private resources away from welfare provision and social security spending towards private developments) is felt hardest by the poorest, most vulnerable citizens. In doing so, The Wire offers what Kinkle and Toscano call a map of 'the dynamics of the contemporary uneven and combined geographical development of capitalism. ${ }^{20}$ Hence it shows us not just how 'the evaporation of working class jobs leads young men into the drug trade ${ }^{21}$ but also how men like Reginald ‘Bubbles' Cousins and Dennis ‘Cutty’ Wise, who eschew the drug trade, are compelled to hustle for a living, and are given little or no support from the state (e.g. in season five, Bubbles must self-treat his addiction, and in season three, Cutty must seek private funding for a gym he is trying to set up for 'ghetto' kids). If, as Spence puts it, 'Under the neoliberal turn, cities and individuals alike are forced to become more and more entrepreneurial bearing the responsibility and risk for a range of actions' ${ }^{22}$ this entrepreneurialism is a 'byproduct of particular social and political forces' that in turn 'hollow out' industrial capacity and 'leave behind' the poor, black population that cannot follow wealthier white people to the suburbs.

Elsewhere I argue that crime fiction is capable of similarly penetrating critiques of public power and that 'the intertwining of public and private interests, of state institutions and commercial businesses, has a long and complicated history. ${ }^{, 23}$ But this critique is typically set against an acknowledgement of the public good of an effective judicial system and that, as a result, 'crime fiction tends to produce a contradictory account of the state as both necessary for the creation and 
maintenance of collective life and central to the reproduction of entrenched socio-economic inequalities. ${ }^{24}$ The notion that crime fiction operates in a field of tension between what we might call liberal and Marxist accounts of the state and of power finds its correlative in Simon's anticapitalist vision of social and political collapse on the one hand, ${ }^{25}$ and on the other, his robust defense of both the police and the political process. 'I believe in governance. I believe in good governance as being a goal,' he claimed in one post-uprising interview, echoing Arendt's defence of political participation over revolutionary violence in On Revolution (1963). ${ }^{26}$ In another interview, he reiterated his general support for law-enforcement as a 'thick' public good, over and above any acknowledgement that large parts of the black population in the US, especially post-Ferguson, would have valid reasons not to concur: 'A lot of people would say that any time the police win a fight, it's police brutality. I would not. Any fight that does happen, the police are supposed to win it, not lose it.. ${ }^{27}$

Simon's commitment to both positions means that he, as a bona fide public intellectual, and The Wire as primarily his creation, struggles to accommodate two related counter-positions, both of which assume an important racial complexion. First, the idea that the police force is institutionally racist and hence fundamentally implicated in what Lisa Miller calls 'racialized state failure': i.e. the militarisation of policing and police violence is directly linked to 'other deeply racialized deadly risks in American society' and hence to the 'relentless attack' on civil rights process, welfare provisions and public services, moves that disproportionately affect black lives. ${ }^{28}$ And second, the notion that black violence as a form of politicized agency might not be reducible to the effects of capitalism as analogised by the drug trade, and may have some role to play in the wider political process.

Turning firstly to The Wire's depiction of the police, I should point out that the series is by no means sympathetic to the police as an institution. For example, it shows how crime prevention effectively equates to shifting the blame from institutions to individuals while requiring middle managers to 'duke the stats' in order to prove that crimes rates are falling (see, for example, series 3, episode 4, hereafter 3:4). However, in light of the deaths of young black men like Michael Brown and Freddie Gray at the hands of the police and the post-Ferguson 
militarisation of the police ('officers clad in Kevlar vests, helmets and camouflage, armed with pistols, shotguns, automatic rifles, and tear gas, ${ }^{29}$ ), we might ask whether the portrayal of the rank-and-file police in The Wire reflects what Kinkle and Toscano call the show's 'nostalgic valorization of the moral economy of work and craft'.$^{30}$ There are two significant incidents of state violence exercised against black people in the third season and both end up exonerating the police force as a whole by playing down the racial dimension. The first involves a drug 'bust' in the Western District where officer Dozerman is shot by a 'gangbanger' when the 'bust' goes wrong (3:2). In the subsequent episode (3:3) the black perpetrator is found and beaten by Dozerman's colleagues, an act that is justified - morally if not legally - by the confession the police elicit. In the second incident, Roland 'Prez’ Pryzbylewski, a white police detective, mistakes a black undercover cop for a suspect and shoots him (3:9). Though Prez is unable to determine with any certainty whether race was a factor in influencing his decision to fire his gun, he takes full responsibility for his actions and resigns. The incident doesn't further inflame racial sensitivities either within the police department or in the wider city, and Prez is rehabilitated in the fourth season when he becomes a teacher in an inner city school. We certainly don't see evidence of the kind of incendiary police brutality that led to the deaths of Gray and Brown, nor even do we see the few 'bad apples': cops who use derogatory racist language and subject black people to random, gratuitous, indiscriminate beatings. This led some bloggers, in the aftermath of the Baltimore uprising, to question whether Simon and his co-producer, Ed Burns, a former Baltimore cop, might be too close to elements within the Baltimore police department. ${ }^{31}$

Spence makes the point that the neoliberal turn has been marked not just by urban disinvestment and savage cuts to welfare spending and social programs but also by the militarization of the police - and he suggests that the move to secure urban space via military means and using a 'military mindset' ('often seeking to use violent methods of policing first as opposed to non-violent ones') may have 'helped generate the recent wave of anti-black police violence. ${ }^{32}$ The Wire is certainly willing to point a finger at the failure of the 'zero tolerance' policy adopted by Baltimore mayor Martin O’Malley (which, as Spence notes, resulted in 667,000 arrests between 1999 and 2005, roughly the period that The Wire $\operatorname{ran}^{33}$ ): countless 
episodes show the pointlessness of arresting street-level dealers, only to see them bailed and back on their 'corners' within hours. But the only evidence of the Baltimore police department patterning itself on a military unit comes at the end of the third season when a decision is taken to close down a ‘free-zone' colloquially known as 'Hamsderdam' where the sale of drugs has been unofficially tolerated. In this episode (3:12) the military iconography and rhetoric are intensified to absurdist levels - Deputy Commissioner Bill Rawls dispatches his 'troops' with the phrase 'over the top, gentleman' and plays a version of 'Ride of the Valkyries' on a portable CD player (an obvious reference to its use in Apocalypse Now). But crucially this encroaching militarisation and references to 'winning the war' and 'taking back the streets' is limited to the effects of the 'war on drugs' which in The Wire's and indeed in Simon's view explains policing failure and increased racial tensions far more than what Miller calls more general 'racialized state failure'. In an interview given after the Baltimore uprising, Simon offered the following insight into Gray’s death and the response to it: 'The part that seems systemic and connected is that the drug war...was transforming in terms of police/community relations, in terms of trust, particularly between the black community and the police department.' ${ }^{34}$

Simon is not necessarily playing down the racialised context of neoliberalism but by explaining the recent wave of anti-black police violence primarily or even solely through the 'war on drugs' as system, he effectively situates this violence within the larger context of the free market where racism is less to blame than the generalised application of market principles. ${ }^{35}$ For example, the military incursion by the police at the end of The Wire's third season does not provoke a violent response on the part of those African-Americans whose territory has been invaded, precisely because the raid is orchestrated as part of the war against drugs, which of course has a racialised dimension but where the police violence is not presented in explicitly racialised terms. Accusations of appeasement are perhaps harsh in light of The Wire's ferocious indictment of neoliberalism elsewhere but herein lies the rub. In so far as The Wire, according to Simon, 'depicts a world in which capital has triumphed completely, labor has been marginalized and monied interests have purchased enough political influence to prevent reform, ${ }^{36}$ the police or at least the rank-and-file police who want to do 'good' are as much victims of the system as 
the people they are tasked with policing. This is where Simon's Marxist structuralism plays out most fully - i.e. where the scope for individuals to institute meaningful change is almost entirely contained by their institutional and systemic contexts. Hence Dreier and Atlas's observation that The Wire as a whole is 'much better at describing the various forms of inequality and injustice in society than at identifying the political opportunities that make mobilizations and reform possible. ${ }^{37}$

Drier and Atlas focus primarily on The Wire's failure to pay more attention to the successful efforts of black Baltimoreans in the 'real' world to 'push powerbrokers to change policies and institutions' and 'make the city more humane and livable. ${ }^{38}$ However, their definition of political mobilisation could be widened to include the kind of violent insurrection witnessed in Ferguson and Baltimore and that is wholly absent from Simon's despairing vision of urban tragedy and collapse. Indeed one could argue that this despairing vision necessarily precludes any instance of politicised black agency or to put this another way, it is hard to imagine how, in The Wire, individual acts of resistance might coalesce into something more threatening to the status quo, i.e. the kind of collective movements that spontaneously organised in response to the police killings in Ferguson, Baltimore and elsewhere. There are of course countless examples of black violence in The Wire - drug dealers killing one another as literal embodiment of dog-eat-dog capitalism - but at no point in the five seasons is this violence directed outwards at the markers of black oppression (e.g. the police, politicians, multi-national corporations). Violence and power, as Arendt argues, are related only in an inverse or negative sense: so that 'Violence appears only where power is in jeopardy' and that while 'Violence can destroy power' as we see when drug kingpin Russell ‘Stringer’ Bell is assassinated at the end of the third season (3:11), 'it is utterly incapable of creating it.' 39

Simon's and indeed Arendt's denunciation of violence as anti-politics stands in stark contrast to Fanon's conceptualization of individual violence ‘as a cleansing force’ and of collective violence as an inevitable product of domination and, potentially at least, as means of remaking the world. ${ }^{40}$ As such, Simon's defense of the old models of nonviolent protest (as 'epic and good' ${ }^{41}$ ) borne of the Civil Rights movement and continued in the form of peaceful 
marches and stirring speeches by black figureheads (and which are implicated in Arendt's definition of 'man as a political being': getting together with his peers, acting in concert ${ }^{42}$ ) is starkly at odds with what Eddie S. Glaude witnessed in Ferguson. Namely, 'a mode of organizing that called to mind a more complex picture of black struggle' and a portrait of 'the power of black political actors long thought apathetic and uninformed: young people, tattooed, with fitted hats, angry, fiercely intelligent and organized. ${ }^{43}$ This last description brings to mind figures like ‘Stringer’ Bell, Avon Barksdale and Marlo Stanfield from The Wire, but their anger, organisational prowess and intelligence are only ever wielded in pursuit of self-interest and to maximise profit. Even a more complex and ambiguous figure like Omar, who in some senses resembles Eric Hobsbawm's ‘social bandit' - i.e. a 'pre-political' figure who instinctively lashes out against the wealthy ${ }^{44}$ - directs his violence only against the drug gangs rather than at the markers of white, capitalist power.

Simon's liberalism, following Arendt, makes it difficult for him to acknowledge the political potential of violence per se, and his structuralist vision of the world (aligned to a Marxist account of capitalism's totality) makes it hard for him, in different ways, to think about what individuals and collectivities can do to confront power. However, the problem may also be symptomatic of crime fiction more generally. That's to say, it may be replicated in the genre's difficulties when trying to accommodate violence that may in one sense be criminal (insofar as it results in damage to property and even loss of lives) but that is premised on the call for social and political upheaval, and which cannot be contained by the state and law. If crime fiction's political vision remains tied, always awkwardly and unwillingly, to the state because it cannot, in the end, ever fully escape its securitizing tendencies, the issue of what to do with political violence will always be fraught. In asking what crime fiction might look like if it permitted revolutionary violence, we are given a terrifying answer in Himes’s Plan B (which I will address in the conclusion). But in the next section, I want to look at Mosley's Always Outnumbered, Always Outgunned (hereafter referred to as Outgunned) in order to think about how best to tackle the accompanying problem of black political agency. 


\section{Always Outnumbered, Always Outgunned - after the LA Riots}

It is unfair to compare Mosley's Outgunned as a response to the LA riots of 1992 with The Wire's relationship to the Baltimore uprising of 2015, given Mosley's text enjoys the advantage of hindsight. But, given this hindsight, and the fact Mosley chose, very deliberately, to set his linked stories in Los Angeles in 1992, it is instructive that the collection as a whole deals with the riots themselves so cursorily. The only story to feature the rioting is 'History' in which Socrates Fortlow, a convicted murderer and rapist who is trying to rebuild his life and atone for past mistakes, refuses to participate in the violence, and remains indoors 'for three days watching the tiny black and white TV screen', despite the fact that:

Every scar on his body and curse in his ear, every sour stomach and sleepless night, every minute in prison, every white girl on a magazine cover, every image in his mind for twenty-seven years of incarceration wanted out in that street. ${ }^{45}$

Mosley's unwillingness to address the riots directly - that is, his refusal to give Fortlow the chance to exert agency and deploy violence as a means of righting perceived wrongs - offer a useful way into the problem of black political violence and agency that lie at the heart of this article. On first glance there would seem to be a considerable distance between Mosley's careful ambivalences and Fanon's endorsement of violence as a cleansing force and violent insurrection as a means of bringing about the end of oppression. But as Frazer and Hutchings point out there is also considerable unease in Fanon's work, especially the final chapter of The Wretched of the Earth, about the bodily effects of violence on both oppressor and oppressed: 'the idea that using violence may be a way to escape being in violence is countered by case after case in which people remained trapped in the violence they have inflicted and suffered. ${ }^{46}$

This unease, as it is manifest in parts of Fanon's work and throughout Mosley’s Outgunned, allows us to think about political agency and embodied violence in a different way: not as products of ordered rational minds or as ways of instrumentally achieving a clearly delineated set of political ends but rather in ways that emphasise their imbrication with the 'negative' affects of fear, anxiety, rage, grief, and confusion - what Sianne Ngai calls ‘the 
predicaments posed by a general state of obstructed agency with respect to other human actors or the social' ${ }^{47}$ If neoliberalism as a social and political project is modeled upon understandings of subjectivity in which the values of entrepreneurship and creativity in turn create the conditions for autonomy, freedom and progress and provide the basis for a rationalist conception of resistance, ${ }^{48}$ this kind of focus challenges the logic informing such a project in a number of important ways. First, the precarity which is the inevitable product of neoliberal economics and the 'negative' effects of this precarity on already marginalised individuals and groups can be made fully visible and scrutinized. Second, Mosley’s decision to place 'negative’ affects like fear, anxiety and rage, which don’t easily translate into recognizable forms of agency, at the heart of his narrative, allow us to see these not as blockages or impediments (to a healthier self) but rather as necessary attributes that allow Fortlow to negotiate the unpredictability of Los Angeles in the early 1990s. This has considerable implications for the crime fiction genre which has traditionally endorsed a more rationalist, positivist model of political agency (i.e. that an ordered, enquiring mind and the capacity to wield violence instrumentally will lead to positive outcomes).

Fortlow is both a product of and, in his past at least, an inflictor of violence. Convicted for murder and rape, and having served a twenty-seven year sentence, he describes himself alternatively as 'the worst you ever seen' (p.19), a violent man who'd 'come up hard and gave as good as he got' (p.56) and someone who 'was afraid of what his hands could do' (p.45). His violence may, in part, be explained by his environment but it is not reducible to it, nor does it constitute him in the present. Contra Fanon, it is not a 'cleansing force' or a means of confronting and overturning oppression characterised in the stories by the ever-present police and the intrusive noise of the police helicopter, so that 'Socrates could feel the breeze from the rotors come in through the poorly insulated roof' (p.27). For Fortlow, then, the issue is to understand his own capacity for violence (and its relationship to circumstance): hence his observation, while contemplating killing a dog, that it was just the 'habit of twenty-seven years behind bars out of fifty-eight' (p.38). Fortlow is willing to exercise violence and is highly competent in this regard - for example in 'Midnight Meeting' where he viciously beats and threatens to kill a black man who himself has terrorised the neighbourhood. But even here his violence 
is best understood as 'affective' - in this instance, of hate and perhaps self-hate ('Socrates stood there a good long while staring. He hated Petis. Hated him’ p.35) - rather than the product of reason whereby cause and effect are directly correlated.

Without the detective's raison d'être and indeed capacity to follow a dedicated line of inquiry and draw the necessary conclusions and with no faith in the revolutionary potential of violence - one reason he avoids joining ‘the raging black men’ (p.153) while LA burns, despite knowing 'he was on a path to violence' (p.154) - Fortlow must negotiate a precarious, imperfect world in a piecemeal manner and come to terms with his own vulnerabilities and limitations. Certainly violence is sometimes necessary and even desirable, as Fortlow tells Darryl, a wayward black adolescent he has taken under his wing, when discussing a gang called the Young Africans: ‘They got their code an’ their colors. They ready to go to war. An’ that's fine. Sometimes you got to go to war. But most of the times you should be helpin’' (p.91). But violence, for Mosley and indeed Fanon, is always embodied, i.e. it is situated 'in the immediate physical experiences of inflicting and suffering violence, and in ongoing bodily existence and orientation. ${ }^{49}$ In other words, it is not characterised as instrumental or cathartic and rarely leads to favourable outcomes for Fortlow or indeed Darryl, his young charge. Some of the most insightful sections of the collection relate to Fortlow's exchanges with Darryl; feeding him and helping him to sleep, encouraging him to come to terms with his own mistakes, showing him the value of fighting and indeed not fighting. 'First you got to survive,' he tells Darryl, 'Then you got to think; think and dream' (92).

While Fanon's insights into the bodily effects of violence, and embodied notions of political agency, are grounded in the long revolutionary struggle against colonialism, Mosley’s are the product of the precarity arising from the confluence of racism and neoliberal economics. Subject to police harassment, bouts of sickness and insomnia, gang violence and bearing all the risks and responsibilities for his actions (as state support is either eroded or withdrawn), Fortlow's response is neither to enact the kind of positive expressions of individual agency we have come to expect of crime fiction protagonists nor to yield to the political pessimism we see in The Wire. Rather his instincts are always communitarian (e.g. to seek help and sustenance 
from within the black community) and to offset the precariousness of his situation with the dignity of waged employment; in this case, as an assistant at the Bounty supermarket where he quickly earns the respect of his fellow workers and bosses. This is not acquiescence - i.e. ceding to the disciplinary norms of the workplace - but rather trying, in halting, not always successful ways, to construct or recreate what Spence calls a usable 'counterpublic' whereby the individualizing imperatives of neoliberalism are countered by initiatives within black communities emphasising grassroots activism, education, engagement with public institutions and a general anti-respectability grounded in 'an attempt to fight for a uniquely black right to the city. ${ }^{50}$

It is here where Mosley's collection comes closest to articulating - and perhaps therefore foreshadowing - the larger concerns of the Black Lives Matter movement. His efforts to safeguard Darryl from the ravages of gang violence require the support of friends and neighbours - a loose alliance of individuals committed to supporting black lives, rather than perpetuating or turning a blind eye to the cycle of black-on-black violence whereby, as Fortlow puts it, 'I thought I knew what I was doin’...Killin’ my own people was just part'a the rules’ (164). Here a black-owned bookshop run according to educational and communitarian rather than market principles that Fortlow visits during the aftermath of the LA riots is presented as embodying an alternative form of revolutionary agency, at least in relation to straightforward political violence: as Fortlow tells the owner, 'You started that store, made room for black men and women, and didn't take no collection and didn't tell 'em what to think...That's revolution, brother, rebellion against the rules' (164). Flanked by power on all sides - and by the ill-effects of racism and neoliberal capitalism - Fortlow invests no real faith in what Luc Boltanski calls the left's traditional 'quest for total revolution' (i.e. revealing and opposing that which 'impedes the full realisation of humanity in order to radically transform social conditions so as to allow the appearance of a new, wholly human person ${ }^{51}$ ). Rather he is a disruptive figure precisely because of this dismissal of absolutes and because of Mosley's characterisation of him in terms of what Ngai calls 'ugly feelings' like frustration, shame, envy and irritation that 'do not lead to or culminate in some kind of purgation or release' but are 'good for diagnosing states of 
suspended agency, ${ }^{52}$ Fortlow has killed and raped; he tries to seduce his friend's wife; he sells evidence to the police for profit; he turns down the offer of work out of pride. As such, he embodies the 'anti-respectability' at the heart of the Black Lives Matter movement. ${ }^{53}$ But he is also a good mentor (to Darryl), a loyal friend, a hard-worker, and someone who has paid a heavy price for the violence he's wielded but who has somehow found a way of carrying on regardless. In this sense, the battered, beaten black dog of the story 'Black Dog' that Fortlow rescues from a hit-and-run accident after assaulting the driver of the car, and that saves Fortlow from a return to prison, because its owner is prepared to testify on his behalf, is testament to this imperfection. This in turn speaks to the kind of agonistic politics or what Giorgio Agamben terms 'means without end' or perhaps politics without ends that most appropriately characterises the Black Lives Matter movement (i.e. where politics is characterised as a series of ongoing struggles against state violence and oppression and where there is no obvious end-point and where the struggle constitutes the politics). ${ }^{54}$ It also speaks about the circumscribed agency that Mosley associates with a more equivocal, less totalizing form of politics and indeed rebellion: 'I'm lucky I made it this far. Me an’ this black dog here. Shit. Me an’ this black dog' (196).

It is here that the form of the linked short story collection perfectly suits its larger political ambitions. The space-time co-ordinates of much crime fiction create an inexorable move towards recovery, knowledge, order and resolution, even this move is only partly achieved or successful. Outgunned is situated in Los Angeles in and around 1992 but insofar as each of the stories has its own linearity (i.e. whereby the overall trajectory of the crime story from crime to investigation to solution is disrupted) and because shifts in the physical setting do not correspond to developments in the narrative (i.e. as the detective seeks to 'solve' the case), the collection as a whole does not, and cannot, make generalised claims about racism, the law, justice, economic opportunity, politics, violence and rebellion. Rather the loosely connected, episodic structure whereby each of the stories has its discreet subject and focus but where characters and concerns from previous stories are sometimes revisited enables Mosley to resist straightforward notions of closure and in turn allows Forlow to respond more ambivalently to his precariousness - acknowledging that, as a poor black man, he is subject disproportionately to the 
ill-effects of police violence, economic injustice and racism but underscoring that this doesn’t preclude reclaiming for himself and others a black right to the city. In 'The Wanderer' he exerts this claim by walking for miles along the beach from Santa Monica to Malibu and beyond, and while as readers we might expect this move beyond South Central LA into wealthier parts of the city might be checked by the police, and develop into ugly confrontation, in actuality he meets an army veteran and his girlfriend and is able to reflect on, and come to terms with, his own violent history. Fortlow may be one step away from poverty and destitution and subject to police arrest and arbitrary imprisonment but as he says at the end of the final story about his dying friend, ‘He don’t need no police car or hospital...He don’t need none’a that shit. And neither do I' (208).

\section{Back to the Future - Himes's Plan B, after Dallas}

If Mosley’s Outgunned begins to address the question of what crime fiction in the era of Ferguson and Black Lives Matter might look like, its ambivalence towards the use of violence even as a political weapon and its complex depiction of politics as ongoing and agonistic give it a muted, circumscribed quality that sits uneasily alongside the mobilisations called for in the wake of continuing police violence against black people. Paradoxically this is where Chester Himes’s Plan B ends up, even though it would seem to endorse organised black violence and agitate for revolutionary change. Himes started Plan B in the mid-1960s, at the time of the Watts riots, but he never completed it and it was published, unfinished, in France in 1983 and not until 1993 in the US. In contrast to The Wire and indeed Outgunned, Plan B begins by openly endorsing the claims of black political violence, so long as it is organised and effective (effective because it is organised), even if Himes himself was pessimistic about the capacities of art to meaningfully intervene in politics. 'I don't believe writers have any effect on politics,' he stated in an interview in 1970. But having said this, he added, 'I think writing should be a force in the world' even if he did not actually believe it was. ${ }^{55}$ Plan B is very much a force in the world, largely because Himes, for the first time, directly embraced the logic of revolutionary violence: 
'Of course, in any form of uprising, the major objective is to kill as many people as you can, by whatever means you can kill them. ${ }^{56}$

The revolution in Plan B is organized by Tomsson Black, who having secured funding from a white philanthropic organization for a project to put African-Americans back to work on a pig farm in the US South, uses this money to send rifles to every black man in the country to use in the cause of 'freedom' ${ }^{57}$ Here, then, is a crime novel that directly embraces the logic of black political violence but more importantly shows us its devastating consequences. In a move eerily reminiscent of the killing of seven police officers in Dallas in July 2016 by Micah Johnson, a nameless black sniper overlooking New York City’s Eighth Avenue opens fire with dead-eye precision at a police cruiser, 'puncturing the roof, shattering the side windows, pounding the drooping blonde heads into splinters of bone and blobs of soft gray brain tissue’ (p.55). The backlash by the authorities is swift and equally violent as a ' $105 \mathrm{~mm}$ canon' lays waste to the upper floors of the tenement building where the sniper has hid himself and white cops 'suddenly rose up from their hiding places and began shooting the fleeing black people down' (p.65). Later in the novel, the logic of this scene is repeated when a funeral procession for the slain police officers is attacked by another black sniper. This time the violence - informed by 'the humiliations and hurts imposed on [the sniper] and all other blacks by whites' (p.180) produces an even more spectacular, and violent, response but by this juncture the problem has mutated across the entire country.

In light of the more contained uprisings in Ferguson and Baltimore, and following Dallas and further disturbances in Baton Rouge and elsewhere, it hard to know what to do with the organised violence of Plan B or indeed how seriously Himes wants us to take his novel as comment on the race riots of his own era. In one sense and given how far the violence escalates beyond its initial scene, it is difficult to see it as anything more than a cultural fantasy. But Himes's reflections on responses to the 'problem' of black political violence shed interesting light on what is at stake when riots occur: 'The white community gets very upset about the riots, while the black people haven't seriously undertaken in advance to commit any great amount of violence; it's just been forced on them. What little violence they have done is actually for 
protection. ${ }^{58}$ In this sense, Himes's observations, and thematisations of these observations in Plan $B$, find common ground with Coates's contention that white commentators who condemned the 2015 riots in Baltimore by starting 'the clock with the violence on Tuesday' necessarily fail to comprehend the extent to which this violence is, and has always been, intimately connected to ‘state-backed violence’ orchestrated against African-Americans but falsely characterised as legitimate because it is 'committed by the law. ${ }^{59}$ What Plan B demonstrates is the consequences of what would happen if state-backed violence against African-Americans was countered not just with violence for the sake of protection or motivated by spontaneous anger but rather in the manner envisaged by Fanon. What it worries about, as Fanon does, is the effects of this escalating violence on all parties. As Himes put it, 'I’ve tried to imagine what would happen, and write it as a documentary. But I've had to stop. The violence shocks even me. ${ }^{60}$

A more immediate problem for Himes was how to assimilate this violence back into the parameters of the crime novel, once it had been unleashed and allowed to run its course. Plan $B$ opens with Himes’s two police detectives, Coffin Ed Johnson and Grave Digger Jones, looking into a death in Harlem but quickly they disappear from the narrative, seemingly irrelevant in the face of the violence unleashed by Black and countered by the police. At the end of the novel, they return, to solve the question of who is arming of the black population, and their enquiries lead them to Black, at which point the narrative stops, with Himes unable or too unwell to finish it. In interviews and notes, Himes made it clear what he intended:

I originally envisioned a general conflict between the races, but in the final scene Coffin Ed and Grave Digger shoot at each other. One of them takes the side of the race brothers, while the other one chooses to uphold the law, not because he feels any loyalty to whites, but because the political and social implications of the rebellion are too much for him. ${ }^{61}$

In the first US edition, which first appeared in 1993, the editors Michel Fabre and Robert Skinner make it clear where the manuscript ends and that 'the following pages are reconstructed from a detailed outline found with the rest of the manuscript' (192). But without Himes's guiding hand, the conclusion where his two police detectives turn on one another is handled too 
quickly and schematically for its full implications to make themselves felt. Rather what we are left with is another version of the same problem I have been trying lay out in this article: namely that the genre, with its historical links to the state, though better suited to the task of mapping the consequences and effects of the violence perpetrated by the state against the black urban poor, struggles to cope when this violence is re-directed, via orchestrated political action, at the police. Perhaps this was one reason why Himes couldn’t finish Plan B and remarked that his ending 'amounted to a kind of literary suicide. ${ }^{9}$

If The Wire cannot acknowledge that orchestrated police violence against AfricanAmericans has become, and perhaps has always been, the norm, rather than the result of an exceptionalism produced by the 'war on drugs' and doesn't want to legitimise the idea of black retaliatory violence, or sanction a formulation of black political agency centrally founded upon violence, Himes's Plan B willingly endorses both of these claims and assimilates them into its narrative, but having done so, struggles to make it cohere as a crime novel. Despite their significant political differences, both texts are, willingly or unwillingly, handcuffed to their object of enquiry - the machinery of justice, however unjust, inept, biased and violent it might be. Only Mosley's Outgunned which shifts its focus from the police and state to the lived experiences of Socrates Fortlow and which reconfigures the crime story as a series of interrelated but discreet episodes whereby any push towards resolution or any end-point is resisted, is able to investigate what violence, black or otherwise, really means (its effects and consequences, both in a positive and negative sense) and whether or what to extent the suspended agency produced by embracing ambivalent or contradictory positions produces the kind of agonistic politics without ends theorised by Agamben. Ultimately Mosley seems to imply that Fortlow's quiet subversions constitutes a more effective, or indeed a more pragmatic, form of political action in the face of the state's violence but it is a form bound to and defined by its ongoing-ness and hence it is unlikely to produce positive or at least clear-cut outcomes in the fight against this violence. 


\section{NOTES}

${ }^{1}$ David Schmid, 'Imagining Safe Urban Space: The Contribution of Detective Fiction to Radical Geography,' Antipode, 27:3 (1995), p.243. 242-269.

${ }^{2}$ Examples of post-BLM (crime) fiction might, paradoxically, include Ben Winters'

Underground Airlines which reimagines the US as a place where the Civil War never happened and where slavery in some states is still practiced (paradoxically because the contemporary is being interrogated through the lens of a counter-factual history); and other contemporary novels where the contemporary legacies of slavery and other systems of racial oppression are explored (e.g. Paul Beatty's The Sellout and Colson Whitehead's The Underground Railroad) and where racial struggles are violent, agonistic and, most importantly, ongoing (i.e. where no 'good'/postracial end-point has been reached).

${ }^{3}$ Ta-Nehisi Coates, Between the World and Me (Melbourne, Australia: Text Publishing, 2015), p.103, p.10.

${ }^{4}$ Coates, Between the World, p.21, p.8.

${ }^{5}$ Lester K. Spence, Knocking the Hustle: Against the Neoliberal Turn in Black Politics (Brooklyn, NY: Punctum Books, 2015), p.xxiii, p.xxiv.

${ }^{6}$ See Arendt, On Violence (New York: Harvest, 1970).

7 “"We're trying to destroy the world": Anti-Blackness \& Police Violence After Ferguson An Interview with Frank B. Wilderson III'. http://sfbay-anarchists.org/wpcontent/uploads/2015/01/frank-b-wilderson-iii-were-trying-to-destroy-the-world-antiblacknesspolice-violence-after-ferguson.pdf [Date accessed: 10 August 2016).

${ }^{8}$ Mosley's more conventional detective novels featuring LA private investigator Easy Rawlins function along these lines, despite the fact that violence is not unproblematically redemptive, Rawlins does not achieve all the answers and 'closure' or 'resolution' is only ever partial.

${ }^{9}$ Elizabeth Frazer and Kimberly Hutchings, 'On Politics and Violence: Arendt Contra Fanon', Contemporary Political Theory, 7 (2008), p.106. 90-108.

${ }^{10}$ Conversations with Chester Himes, ed. Michel Fabre and Robert E. Skinner (Jackson: University Press of Mississippi, 1995), pp.93-94.

${ }^{11}$ See Andrew Pepper, 'Chester Himes' unfinished crime novel is an unsettling portent of Dallas shootings,' The Conversation, 12 July 2016. https://theconversation.com/chester-himesunfinished-crime-novel-is-an-unsettling-portent-of-dallas-shootings-62362 [Date accessed: 10 August 2016].

${ }^{12}$ See, for example, Scott Timberg, 'You won't learn everything you need to know about Baltimore from “The Wire,” but it’s a start', Salon, 28 April 2015.

http://www.salon.com/2015/04/28/you_wont_learn_everything_you_need_to_know_about_balti more_from_the_wire_but_its_a_start/ [Date accessed: 10 August 2016].

${ }^{13}$ David Simon wrote: 'But now - in this moment - the anger and the selfishness and the brutality of those claiming the right to violence in Freddie Gray's name needs to cease.' 'The Audacity of Despair,' (blog), April 27 2015, http://davidsimon.com/page/2/ [Date accessed: 10 August 2016].

${ }^{14}$ See Arendt, On Violence.

${ }^{15}$ Simon, 'The Audacity of Despair'.

${ }^{16}$ See Sonia Saraiya, 'You tell me that the riots are a good thing?' Salon, August 52015. http://www.salon.com/2015/08/04/you_tell_me_that_the_riots_are_a_good_thing_fck_you_com e to baltimore and say that david simon on police brutality the legacy of the wire and $t$ he_future_of_american_cities/ [Date accessed: 10 August 2016].

${ }^{17}$ Dave Zirin, “"The Game Done Changed”: Reconsidering The Wire Amidst the Baltimore Uprising', The Nation, 4 May 2015, http://www.thenation.com/article/game-done-changedreconsidering-wire-amidst-baltimore-uprising/ [Date accessed: 10 August 2016].

${ }^{18}$ Ta-Nehisi Coates, 'Nonviolence as Compliance', The Atlantic, 27 April 2015, http://www.theatlantic.com/politics/archive/2015/04/nonviolence-as-compliance/391640/ [Date accessed: 10 August 2016]. 
${ }^{19}$ This is where Simon's Marxism is brought most heavily to bear on The Wire and it is striking how closely the Marxist geographer David Harvey's appraisal of the slow death of Baltimore mirrors what takes place in The Wire. See Harvey, Spaces of Hope (Edinburgh: Edinburgh University Press, 2000), pp.133-156.

${ }^{20}$ Jeff Kinkle and Alberto Toscano, Cartographies of the Absolute (Winchester UK: Zero Books, 2015).

${ }^{21}$ Kinkle and Toscano, Cartographies.

${ }^{22}$ Spence, Knocking, p.38

${ }^{23}$ Andrew Pepper, Unwilling Executioner: Crime Fiction and the State (Oxford: Oxford University Press, 2016), p.2.

${ }^{24}$ Pepper, Unwilling, p.2.

${ }^{25}$ This is where Simon's Marxism is brought most heavily to bear on The Wire and it is striking how closely the Marxist geographer David Harvey's appraisal of the slow death of Baltimore mirrors what takes place in The Wire. See Harvey, Spaces of Hope (Edinburgh: Edinburgh University Press, 2000), pp.133-156.

${ }^{26}$ See Chotiner, 'Everything'; Hannah Arendt, On Revolution (New York: Viking, 1963).

${ }^{27}$ Saraiya, 'You tell me'.

${ }^{28}$ Lisa Miller, 'Racialized State Failure and the Violent Death of Michael Brown', Theory \& Event, 17:3 Supplement (2014).

${ }^{29}$ James Bouie, 'The Militarization of the Police', Slate, 13 August 2014.

http://www.slate.com/articles/news_and_politics/politics/2014/08/police_in_ferguson_military weapons_threaten_protesters.html [accessed 10 August 2016].

${ }^{30}$ Kinkle and Toscano, Cartographies.

${ }^{31}$ See Simon, 'The Audacity of Despair'.

${ }^{32}$ Spence, Knocking, p.125.

${ }^{33}$ Spence, Knocking, pp.125-126.

${ }^{34}$ Bill Kellner, 'David Simon on Baltimore’s Anguish', The Marshall Project, 29 April 2015, https://www.themarshallproject.org/2015/04/29/david-simon-on-baltimore-s-anguish [Date accessed: 10 August 2016].

${ }^{35}$ Spence, Knocking, p.49.

${ }^{36}$ David Simon, 'Introduction', in Rafael Alvarez, The Wire: Truth Be Told (Edinburgh: Canongate, 2009), p.30.

${ }^{37}$ Peter Dreier and John Atlas, ‘The Wire: Bush-Era Fables about America's Poor?' in The Wire: Race, Class, and Genre, Liam Kennedy and Stephen Shapiro, eds. (Ann Arbor MI: University of Michigan Press, 2012), p.130

${ }^{38}$ Dreier and Atlas, 'The Wire', p.133.

${ }^{39}$ Arendt, On Violence, p.56.

${ }^{40}$ Franz Fanon, The Wretched of the Earth, trans. Constance Farrington (London: Penguin, 2001), p.74

${ }^{41}$ Saraiya, 'You tell me'.

${ }^{42}$ Arendt, On Violence, p.82.

${ }^{43}$ Eddie S. Glaude Jr., ‘A Requiem for Michael Brown/A Praisesong for Ferguson', Theory \& Event, 17:3 Supplement (2014).

${ }^{44}$ E.J. Hobsbawm, Primitive Rebels; Studies in Archaic Forms of Social Movement in the 19thy and $20^{\text {th }}$ Centuries (Manchester: Manchester University Press, 1971).

${ }^{45}$ Walter Mosley, Always Outnumbered, Always Outgunned (London: Serpent's Tail, 1997), 153. All subsequent citations are given parenthetically in the text and refer to this edition.

${ }^{46}$ Frazer and Hutchings, 'On Politics', p.98.

${ }^{47}$ Sianne Ngai, Ugly Feelings (Cambridge MA and London: Harvard University Press), p.3.

${ }^{48}$ See Rachel Greenwald-Smith, Affect and American Literature in the Age of Neoliberalism (Cambridge: Cambridge University Press), pp.2-6.

${ }^{49}$ Frazer and Hutchings, 'On Politics', p.105.

${ }^{50}$ Spence, Knocking, pp.139-40. 
${ }^{51}$ Luc Boltanski, 'The Left After May 1968 and the Longing for Total Revolution', Thesis Eleven, 69 (May 2002), p.1, p.3. 1-20.

${ }^{52}$ Ngai qtd. in Debbie Lisle, 'Waiting for International Politics Sociology: A Field-Guide to Living In-Between', International Political Sociology (forthcoming).

${ }^{53}$ Spence notes that mobilisations by BLM 'on behalf of those who have been far from respectable' is an important part of the movement's mission. See Knocking, pp.139-140.

${ }^{54}$ Agamben puts it as follows: 'What is in question in political experience is not a higher end but....being-into-a-mean as an irreducible condition of human beings...Politics is the sphere neither of an end in itself nor of means subordinated to an end.' Means Without End: Notes on Politics, trans. Vincenzo Binetti and Cesare Casarino (Minneapolis: University of Minnesota Press, 2000), pp.115-116.

${ }^{55}$ Conversations, pp.88-89.

${ }^{56}$ Conversations, pp.44-45.

${ }^{57}$ Chester Himes, Plan B, ed. Michel Fabre and Robert E. Skinner (Jackson: University Press of Mississippi, 1993). All subsequent citations are given parenthetically in the text and refer to this edition.

${ }^{58}$ Conversations, pp.45-6.

${ }^{59}$ Ta-Nehisi Coates, 'The Clock Didn’t Start with the Riots', The Atlantic, 30 April 2015, http://www.theatlantic.com/politics/archive/2015/04/ta-nehisi-coates-johns-hopkinsbaltimore/391904/ [Date accessed: 10 August 2016].

${ }^{60}$ Conversations, p.22.

${ }^{61}$ Conversations, p.136.

${ }^{62}$ Conversations, p.136. 